\title{
THE ROLE OF SOCIAL MEDIA IN SOCIAL MOVEMENTS:
}

\section{THE CASE OF BLACK LIVES MATTER}

by

Jordan Hamilton

\author{
Submitted in partial fulfillment of the \\ requirements for Departmental Honors in \\ the Department of Marketing \\ Texas Christian University \\ Fort Worth, Texas
}

May 2, 2016 
THE ROLE OF SOCIAL MEDIA IN SOCIAL MOVEMENTS:

\title{
THE CASE OF BLACK LIVES MATTER
}

Project Approved:

\author{
Supervising Professor: Dr. Stacy Grau \\ Department of Marketing
}

Ebony Rose,

Department of Student Development Services 


\begin{abstract}
$\underline{\text { ABSTRACT }}$
The motivation for this thesis is to explore the social movement of Black Lives Matter to discover and analyze the reasons for its formation, associated events that have taken place, and most of all the societal impact the movement has had on America and social media's role in the process. Social media and social movements will be examined with specific regard to the Black Lives Matter movement with the theories of collective identity, examples of recent social movements, slacktivism and the role racial injustice in the $21^{\text {st }}$ century. Through collective identity, this thesis will show that a shared sense of "we-ness", emotional investment and a dissociative group are extremely important to create a collective and lay the foundation for a social movement to form. Slacktivism will display that meaningful forms of activism like protest should be coupled with token (non-meaningful) forms of support to achieve the meaningful and lasting change desired. This thesis will also illustrate how racial injustice has been engrained into American society for scores of years leading up to the formation of the Black Lives Matter movement, whether that be in policies promoted and endorsed by political candidates or through school segregation. It will be demonstrated that racial injustice is real and has to be addressed in constructive ways. The Black Lives Matter movement will be examined from its beginning through the immediate events that led to its creation and indicate some of the impact that it has had in America to prove that Black Lives Matter is the culmination of a history that has consistently said that black lives do not matter.
\end{abstract}




\section{Table of Contents}

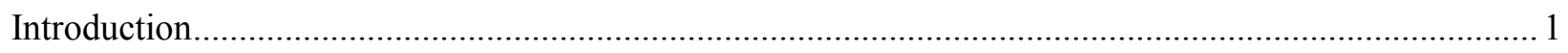

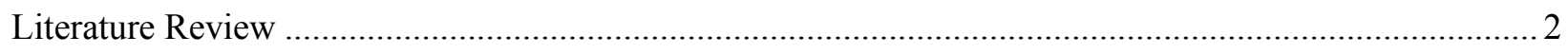

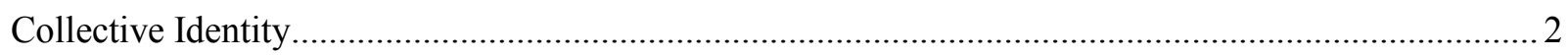

Examples of Social Media and Social Movements.................................................................... 5

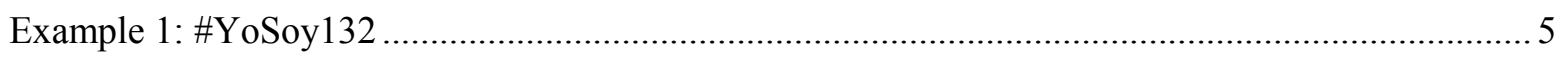

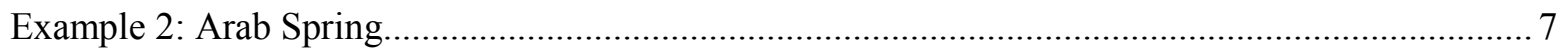

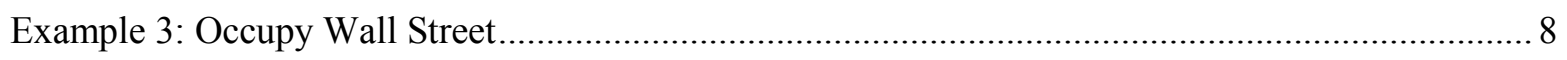

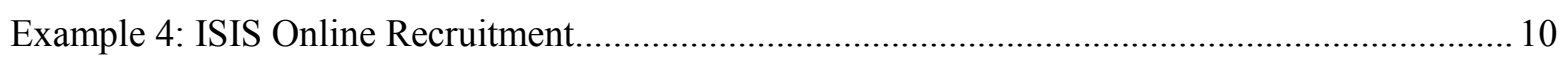

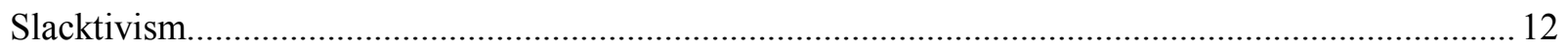

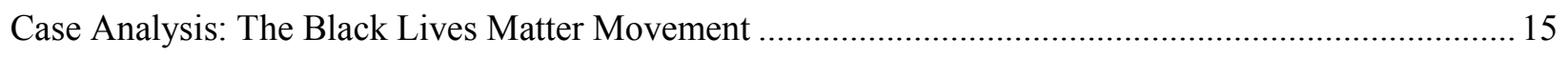

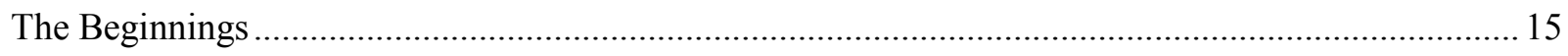

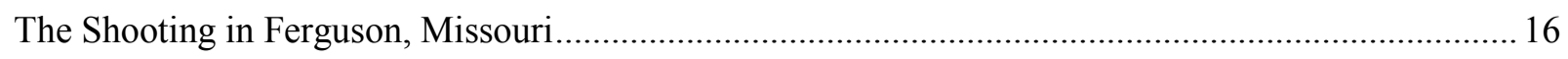

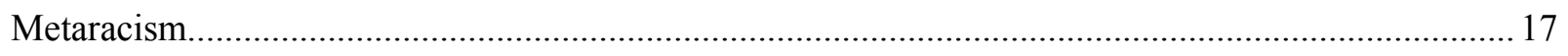

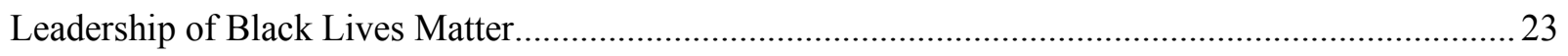

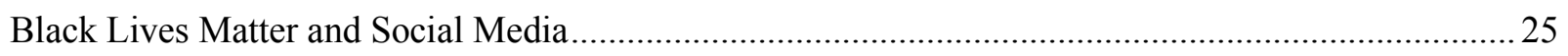

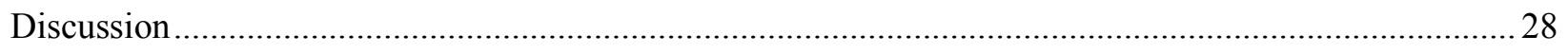

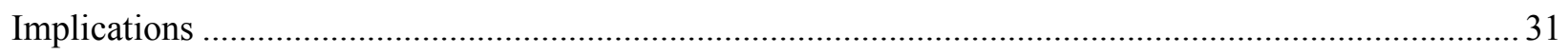

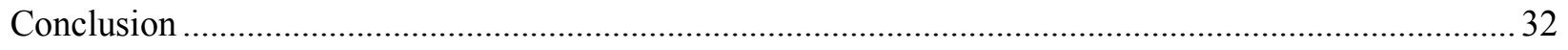

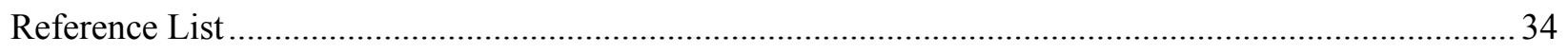




\section{Introduction}

Since the development of Web 2.0, social media has grown to become an integral part of our everyday lives. People aged 15-19 spend an average of three hours on social media while people 20-29 spend an average of two hours a day (Social Media Addiction 2014). “Today's media involve human networks that enhance connectivity; in other words, social media facilitate interaction among people and connote a social value" (Hwang and Kim, 2015, 478). Social media enhances connectivity between friends, families, colleagues, celebrities and their fans, and the world and its news.

Social movements have been the driver behind overwhelming societal changes and paradigm shifts for hundreds of years. Social movements are characterized as "an effort by a large number of people to solve collectively a problem that they feel they have in common" (Hwang and Kim, 2015, 478). In America's short history, social movements have radically shaped the history of this country: The American Revolution, Abolishment of Slavery, Women's Rights, Civil Rights and more recently, the Human Rights movements. These movements have the power to unite massive amounts of people under one cause.

Although social movements have been around for centuries, these movements began employing the use of social media to further the various causes and gain widespread support over the last several years. "Social media have greatly empowered protestors [movements] in three key areas: public attention, evading censorship, and coordination or logistics” (Tufekci, 2014, 2). Social media and social movements have been studied in how it relates to social capital, governments and in specific movements around the world such as the \#YoSoy132 movement in Mexico and the overthrow of the Egyptian government. However, there has been little to no research on the current social movement that has swept the entire nation over the last year: Black 
Lives Matter. This movement has been deemed the new civil rights movement (Day, E. 2015). Unlike other movements, it did not start as an organization that employed the use of social media. It is the first, domestic, social justice movement that started on social media.

Through theory-based research this thesis will examine the role social media has played in social movements by exploring the theories of collective identity, slacktivism and racial injustice, as it applies in the 21 st century. All of these elements will be used in a case study analysis of the Black Lives Matter movement.

\section{Literature Review}

\section{Collective Identity}

Collective identity is an integral part of the discussion of social movements and their success. It is one of the components that unites the people in a movement together. Collective identity has many definitions. According to Polleta and Jasper (2001), "collective identity [is located] within the individual, defining it as: 'an individual's cognitive, moral and emotional connection with a broader community, category, practice, or institution' (p. 285)" (Fominaya, 2010, 394). Another definition of the term from Whittier (1995) is that "collective identity [is] located in action and interaction-observable-phenomena-rather than in individual self-conceptions, attitudes, or beliefs (p. 16)" (Fominaya, 2010, 394). Finally, "Melucci (1996) views collective identity as 'an interactive and shared definition produced by a number of individuals (or groups at a more complex level) concerning the orientations of their action and the field of opportunities in which such action is to take place"' (Kavada, 2015, 874). All of these definitions of collective identity are credible and accurate. However, Melucci's definition is the one that will be primarily used for this thesis. This definition is sufficient because of its alignment to purpose and mission of Black Lives Matter. The movement is composed of a massive number of individuals that feel as an entire race of people have been oppressed in the past, the present and will be in the future, if 
the current situation continues as it always has. Black Lives Matter has taken the unfortunate culmination of the oppression they have felt via the multiple killings of unarmed, black teenagers by white police officers as their opportunity to shed light on the systemic racism that is present in this country.

Collective identity encompasses several aspects of a group. "At its most basic level, it is a shared sense of "we-ness"” (Trere, 2015, 903). It is a sense of "together-ness". Individuals come together and bond underneath this big concept of collective identity, which they most likely do not know exists. What the individuals do know is that they have some sort of shared beliefs, goals, or passions that have brought them together. More than that though, collective identity has three additional analytical tools: boundaries, consciousness, and negotiations (Trere, 2015 and taylor and Whittier, 1992).

With boundaries, they refer to the social, psychological, and physical structures that establish differences between challenging groups and dominant groups. Consciousness denotes instead the interpretive frameworks that emerge out of a challenging group's struggle to define and realize its interests. Finally, negotiation entails the symbols and everyday actions subordinate groups use to resist and restructure existing systems of domination (Trere, 2015 and Taylor and Whittier, 1992).

Melucci (1996) did not believe that collective identity was one collection of a groups' beliefs and ideals like many others. There could be multiple diverse ones. As a result, some of the groups' beliefs, ideologies and goals can differ (Fominaya, 2010, 395). Collective identity is composed of the groups' beliefs and common practices, and we must understand that a collective forms through "multiple and heterogeneous social processes" (Kavada, 2015, 875). One important factor in these processes is the need for the emotional involvement of the people 
involved (Fominaya, 2010,395). When participants become emotionally involved in the collective, the connection to the collective becomes stronger. This is especially important during times of disappointment such as the group not meeting its political goals. A positive emotional experience will keep activists invested, whereas, a negative emotional experience can deter an activist even in times of success for the group (Fominaya, 2010, 395). Therefore, the collective must foster positive emotional experiences to retain the individuals that compose the collective.

An essential factor in a collective forming is the presence of a dissociative group. The individuals come together in part because they are all associating themselves with each other as a way to distinguish themselves from the "other" (Fominaya, 2010, 395). In the case of Occupy Wall Street, the "other" was the people of Wall Street and the top 1\% of America. For the \#YoSoy132 Movement, it was the oppressive Mexican government, and for the Black Lives Matter movement the other is the systemic racism that is built into the American Justice System and America in general. "The process of establishing what 'we are' inevitably involves establishing what 'we are not"' (Fominaya, 2010, 395). If the 'other' is not identified, then one of the important analytical tools does not exist: boundaries. As the "other" is being established within the collective, it is usually in opposition to the dominant practice of the time. They are resisting the norm and what is accepted because they feel that in some way it is fundamentally wrong. The movement that the collective has formed seeks to restructure the status quo (Fominaya, 2010, 396).

Another argument that must be discussed on the topic of collective identity is whether it is a 'process' or a 'product'. There are arguments for both sides. The 'product' definition is that "collective identity is something people outside the movement recognize and respond to (whether they are antagonists or sympathizers or even potential members) is 
fundamentally different from the 'process' definition..., [which] is more concerned with shared meanings, experiences and reciprocal emotional ties as experienced by movement actors themselves through their interaction with each other" (Fominaya, 2010, 397).

The 'product' definition is concerned with the definition of the collective to the public and distinguishing themselves from "other". While the 'process' definition is concerned with the group's interactions. A part of the reason for the confusion between product and process is because collective identity was being researched at the time of the rise of the identity movements such as feminism and gay rights. Due to this, collective identity sometimes becomes synonymous with the personal identities of the group of individuals that make up the movements (feminists, gay, black, white). Although collective identity is important in these movements as well, the collective and personal identities are still separate. There is a distinction between personal, social and collective identities. Personal identities are those a person assigns to themselves, and social identities are used by people to classify or categorize others into certain social roles to make people easier to understand. Buechler (2000) "argues that collective identity should be understood in terms of a continuum, with structurally and historically given identities at one end and collective identities that must be formed from 'scratch' at the other" (Fominaya, 2010, 398).

\section{Examples of Social Media and Social Movements}

There are many examples of social media influencing the outcome and perpetuating a social movement. However, only four of them will be discussed here: The Mexican \#YoSoy132 Movement, Arab Spring, Occupy Wall Street, and ISIS recruitment online.

\section{Example 1: \#YoSoy132}

The \#YoSoy132 movement in Mexico began after the Mexican president and other leading officials of the ruling party defended the unfair, violent actions of police against 
university students (Trere, 2015, 906). These students were characterized as "thugs, violent, fascist, and intolerant, going so far as to deny their affiliation with the university" (Trere, 2015, 906). The two media networks that capture $99 \%$ of the viewing audience in Mexico were on the side of the ruling party. These networks showcased the president in a positive light against the protesters and had been strategically supporting the ruling party in prior years.

To dispute the accusations made by the media and politicians, the 131 violently repressed students created a YouTube video displaying their university credentials to show they were actually students. The video was widely successful and gained support across the country from other students. That support birthed the \#YoSoy132, meaning "I'm 132". This was to show that these students stood with those first 131 persecuted students (video link: https://www.youtube.com/watch?v=oVvju2E3qcc).

The goal of the movement was to "democratize mass media, in order to guarantee transparent, plural and impartial information to foster critical consciousness and thought" (Trere, 2015, p. 907). The movement presented solutions to democratize the media, and for the first time in Mexican history successfully used social media and radio stations to show an electoral debate.

The \#YoSoy132 movement is applicable to the Black Lives Matter Movement because it involves college students. College students were the ones that started the movement. They recognized the injustices of the events that took place against other university students and took action through social movement. Historically, this kind of action by college students has fueled social movements since the Civil Rights Movement of the 1960's. College campuses have been a hot bed for progressive thinking individuals that are unafraid to stand up for what they believe in, especially when they see unfair treatment. The Black Lives Matter movement has been no different. Although the movement did not start on a college campus (as will be discussed in 
depth later in the paper), college students have eagerly and fearlessly adopted the movement and taken action on their campuses. There have been several examples of this action within the last year, including the University of Missouri.

\section{Example 2: Arab Spring}

From 1981-2001, Egypt had been under the authoritarian presidency of Hosni Mubarak. During his presidency, the country suffered from a slow economy, 20\% of Egyptians lived below the poverty line, and there was a steadily growing wealth gap" (Kamel, 2014, 78). The country was filled with "corruption, lawlessness, unemployment and violations of human rights" (Kamel, $2014,79)$. One of the most important factors in the critical role social media played in the coming revolution was the fact that $58 \%$ of the population was under the age of 25 . This age group was filled with passionate people that wanted a better future for themselves.

The Egyptian Revolution occurred in January of 2011, and social media played a pivotal role. However, it cannot be said that the sole cause of the revolution occurred because social media existed. Negative sentiments and unrest were already highly present within the society. Social media had multiple purposes within the revolution, but the overall use was to speed up the flow of information and organizational efforts.

According to Kamel and Shapiro (2014, 2009):

While Facebook was used mainly to exchange excessive audiovisual content, write-ups, and in the formulation of discussion groups. Twitter was used for logistical purposes on where to meet, what to avoid and how to deal with tear gas among uses. Flickr was used to post photos of different incidents and locations and YouTube was instrumental in documenting all sorts of developments taking place across Egypt (p. 83).

Through these forms of social media and potentially others, over 5 million people were encouraged to further the cause by protesting in some form (Kamel, 2014, 78). 
The result of the protestors' efforts and actions was the overthrow of the Egyptian government. The use of social media during the revolution worked so well that the government blocked all communication channels to attempt to stop the revolution. However, that move by the government upset the international community and the revolt continued despite the government's action and ended in success. The events that took place in Egypt showed the world that social media was a powerful tool that had the ability to be used to coordinate and unite millions of people under one cause and incite positive and lasting change. After the revolt, Egypt elected Mohamed Morsi during their first free parliamentary election. However, due to his authoritarian rule, a military coup was formed in 2013 (Egypt). Finally, a new election was held and Abdel Fattah el-Sisi was elected president in 2014 (Egypt).

Arab Spring has relevance to the Black Lives Matter Movement, as well. The result of the activism was the overthrow of the oppressing government. Although the Black Lives Matter Movement has not and does not intended to overthrow the government, it has caused change at the state and federal level. This change has come in response to the police brutality that sparked the movement. Police officers and departments across the country are taking steps to reduce police brutality and to hold those responsible for committing the acts of brutality responsible such as new training and police officers wearing body cameras when they are out on patrol. Example 3: Occupy Wall Street

The Occupy Wall Street movement began on September 17, 2011 (Ngak, 2011) and is one of the first social justice movements of the current generation. It is largely thought to be focused on income equality; however, income equality is an effect of the root cause. The root cause is the severing of the relationship between productivity and the wages of median workers. Nonetheless, the mantra of the movement is "We are the $99 \%$ " because the top $1 \%$ of the country earn $25 \%$ of the nation's income, and have $40 \%$ of the nation's wealth. This gap has increased 
over the last three decades from $12 \%$ and $33 \%$ respectively, and this can be linked to the severing of the productivity and wages relationship (Harvard International Review, 2012, p. 13). Since the 1980's, productivity has increased $80 \%$, however, hourly wages have only increased by a little more than $10 \%$. Over time, this small growth in hourly wages, has left a stark gap between classes. Furthermore, the movement is bringing national attention to the power that major banks and multinational corporations have over the political environment.

According to the Harvard International Review (2012):

The majority of our politicians are members of the top 1 percent when they arrive, are kept in office by money from the top 1 percent, and know that if they serve the top 1 percent well they will be rewarded by the top 1 percent when they leave office (p. 13).

The initial Occupy Wall Street protest was announced by Adbusters on their blog to have 20,000 people set up camp for a few months in lower Manhattan. From there, social media, especially Twitter, was used to organize and coordinate before, during, and after events and to disseminate information to keep the protesters up to date. For the main protest in New York City, Twitter was used to communicate with the people attending the protest. Videos were posted on YouTube and other video sharing sites to show the events that were going on. The movement started out small, but the mainstream media picked up some of the social media content and began airing it on national TV, which garnered more support for the movement (Ngak, 2011).

Although the large demonstrations occurred over four years ago, the movement had an impact. The majority of people in America now believe that inequality exists in the nation and is an important issue. Politicians and the President began having conversations on how to address the issue, especially since the world was slowly recovering from the 2008- 2009 global recession (Harvard International Review). Even today in 2016, conversations about how to address the 
growing gap between the top $1 \%$ and the rest of country are still on the table. One of the concerns of 2016 presidential elections is how to bring back the middle class of America that built this country.

The Occupy Wall Street Movement holds relevance to the Black Lives Matter Movement for three key reasons. The first one is that it is the only domestic example given. Black Lives Matter is a movement that started in America and focuses on the oppression of AfricanAmericans. The other examples focused on international activism. The second reason Occupy Wall Street has relevance is that it focuses on economic challenges of the country. Black people have faced economic hardship throughout their entire history in the United States and are still facing it today. Although most races and groups of people have faced and continue to face economic hardship blacks have been worse off than others. According to Forbes, the typical white household has 16 times more wealth than the typical black household (Shin, 2015). This economic disparity is one of the issues that Black Lives Matter stands up against. The third reason, and arguably most important, is the similarity in the marginalizing groups of people by the majority. In Occupy Wall Street, it is the top $1 \%$ that holds $40 \%$ of the nation's wealth, and leaves the other $60 \%$ for the other $99 \%$ of people in America. In Black Lives Matter, it is White America marginalizing and oppressing Black America.

Example 4: ISIS Online Recruitment

Islamic State in Iraq and Syria (ISIS) is a terrorist organization established in 2004 during the war between America and Iraq. ISIS has similarities and ties to Al Qaeda, who the U.S. was fighting against during the war in Iraq and Afghanistan. ISIS has "declared the establishment of a 'caliphate' - a state governed in accordance with Islamic law, or Sharia, by God's deputy on Earth, or caliph" ("What is 'Islamic State"”). They restore God's earth and eliminate any barriers to their mission. ISIS has anti-Western beliefs and believe their way is right and holy. They 
demand that all Muslims swear allegiance to their leader, Abu Bakr al-Baghdadi. Much of this mantra is similar to what Al Qaeda stood for and numerous ISIS supporters were members of the Al Qaeda. However, ISIS is more powerful and more dangerous than Al Qaeda (Thompson, Greene, \& Mankarious, 2015).

ISIS has been able to take and maintain control of much more territory than Al-Qaeda. They act much more like a military force than a terrorist organization. Once they have effectively conquered a territory, they establish a government with a structure very similar to those of the West. Along with the territory, they have gained control of some of Syria's oil assets. It is believed that this oil has made its way onto the black market and is bringing in $\$ 1$ to $\$ 3$ million a day for the organization. These two factors worry Western official immensely because it makes them much harder to stop (Thompson, Greene, \& Mankarious, 2015).

What is even more worrisome for American officials is that ISIS has begun to recruit people through social media. They send short, video messages filled with propaganda of "come and join us" that shows the organization in a light that is more positive than negative. These messages leave out the bloody, gory, violent parts of the organization. Most people will be able to ignore these messages. However, the select few that will be receptive of the message and become ISIS sympathizers is all the organization needs to carry out their missions. Unfortunately, for a terrorist attack to occur, there does not need to be many terrorists involved (ISIS uses social media to recruit allies 2014).

Twitter was one of the first public forum the Islamic State group employed for recruitment, but the group has now expanded its social-media use to several other platforms, including Facebook, Instagram, JustPasteIt, Pinterest and WordPress. One 
group sympathizer even wrote an eBook about joining the organization and posted it to Scribd (Masi, 2015).

Hashtags are incredibly important to the organizations recruitment tactics. They become very popular among the Jihads and these hashtags change almost hourly. They have sympathizers that are recruiters on the internet to screen out the potential spies from the ones that are truly committed to the cause. Once a recruit proves they are real, the recruiter will put them in contact with the appropriate people.

Twitter and other companies have been working to shut down accounts related to ISIS. However, as soon as one account is blocked, another one pops up and immediately begins tweeting to other members and continually recruiting. Although it presents a major problem that ISIS has begun to recruit through social media, it does give officials the unique opportunity of potentially being able to track suspicious activity and people that communicate with ISIS to do their best to stop an attack before it happens.

Although this is a negative and destructive example of how social media can be used, it still illustrates the point that social media can be used as a successful recruitment tool for movements. ISIS has effectively employed the use of social media networks to further their “cause”. The Black Lives Matter movement wants to successfully garner support, increase meaningful activism and incite positive change for cause the promotes opportunity and equality.

\section{Slacktivism}

The examples given above all display forms of activism that have either began online or began traditionally and moved online. All of these movements have incited action online and in real life among the people who have truly believed in the cause. Although these movements were successful in translating online action into traditional, real life activism and vice versa, this is not the case with many of the "social movements" of today. With the advent of Web 2.0, social 
media websites have integrated themselves into our daily lives. In regards to social movements, social media have created positives such as spreading awareness and reaching larger audiences faster than traditional activism (Bregstone \& Chavez, 2012). However, social media sites have led to a phenomena called "slacktivism". This is defined as "a willingness to perform a relatively costless, token display of support for a social cause with an accompanying lack of willingness to devote significant effort to enact meaningful change" (Kristofferson, White \& Peloza, 2013). Examples of token support are anything that "allows consumers to affiliate with a cause in ways that show their support to themselves or others, with little associated effort or cost" such as "signing a petition, wearing a bracelet or pin in support of a cause, or engaging in various forms of support such as liking or joining a page on Facebook" (Kristofferson et al., 2013).

These token displays of support have received praises and criticisms as the use of them have become more popular among advocacy groups. Supporters of slacktivists believe that the people who participate in these token displays of support have an increased chance of participating in more meaningful forms of support, such as donation of time or money, in the future (Seay, 2014). However, critics of this method do not believe that token forms of support will necessarily lead to more meaningful engagement (Essig, 2014). In Seay (2014), she cites the study by Kristofferson et al. (2012) stating:

Importantly, the socially observable nature (public vs. private) of initial token support is identified as a key moderator that influences when and why token support does or does not lead to meaningful support for the cause. Consumers exhibit greater helping on a subsequent, more meaningful task after providing an initial private (vs. public) display of token support for a cause. 
Despite this criticism, campaigns still target slacktivists "based on the logic that increased awareness of a cause is in and of itself a worthy reason to pursue them" (Seay, 2014). Some advocacy groups believe that the more attention a cause gets, the more likely that government officials will donate money to help fund the cause.

One of the practical applications found by the Kristofferson et al. (2012) study was that when people felt their values aligned with the cause or organization, they were much more likely to participate in more meaningful forms of support beyond the token forms. As a result of this finding, charitable organizations and causes are encouraged to promote the values it stands for so as a means to recruit more meaningful supporters.

Slacktivism is very relevant to the Black Lives Matter movement. This movement has enjoyed incredible amounts of support (and criticism) from national media and social media. Whenever social media is involved in activism, slacktivism must be addressed. According to NBC News (Ortiz 2015), \#BlackLivesMatter was the eighth most tweeted hashtag of 2015, and according to CBS News (Top Twitter Topics of 2015), it was tweeted over 9 million times in 2015. With the hashtag of Black Lives Matter being used so much, the question arises, did this online activism spur traditional activism and other forms of meaningful support? It would be a fair statement to say that at the very least, some of the token displays of support turned into more meaningful displays of support due to the accomplishments of the movement in 2015. As a result of the activism of Black Lives Matter protestors,

Democratic candidates Bernie Sanders and Martin O’Malley rushed to release detailed criminal-justice platforms after high-profile clashes with Black Lives Matter activists... [President] Obama called for an end to transfers of certain kinds of military-style equipment from the federal government to police departments. The Federal Bureau of 
Investigation announced a new effort to improve its tracking of fatal police shootings. Chicago Mayor Rahm Emanuel and Baltimore Mayor Stephanie Rawlings-Blake fired their police chiefs amid protests over police brutality... High-profile protests at the University of Missouri and Yale University over discrimination and racial insensitivity led to resignations at both schools (Foran 2015).

These are only a few of the things that the movement accomplished within the year 2015 , so it is safe to say that not all of the online activism stayed strictly online.

\section{Case Analysis: The Black Lives Matter Movement}

\section{The Beginnings}

The Black Lives Matter movement that has swept the country over the last couple of years was actually unintentionally started. The event that birthed the movement was in the summer of 2013 at the conclusion of the trial of State of Florida v. George Zimmerman. Zimmerman, a white male, was accused of shooting Martin, an unarmed, black teenager from Florida, in cold-blood. Zimmerman's side of the story was that Martin was attacking him, and Zimmerman used self-defense to protect himself from being assaulted, which resulted in Zimmerman shooting Martin. Unfortunately, only two people knew the true events of the shooting, and one of them was dead. The case went to trial, and the jury was composed of six women, five were white and one was a minority. The composition of the jury was an immediate issue for people due to it being predominantly white and all women. The trial "inflamed passions for well over a year, much of it focused on race" (Botelho \& Yan, 2013). In the end, Zimmerman was found not guilty. This enraged some and satisfied others. Alicia Garza, Patrisse Cullors, and Opal Tommetti were enraged. These women began conversations with people around them and those online. Garza ended a Facebook post on her personal page with "it was time to organize and ensure "that black lives matter"' (Ross, 2015). This post inspired Cullors to shorten the 
phrase to just "Black Lives Matter" and attach a hashtag to it to create \#BlackLivesMatter. With the creation of the hashtag, the idea caught on and the movement began. The women worked their day jobs and at night tirelessly worked to spread the movement and the idea that black lives truly did matter. Months later, this movement was deemed by New York Times the " $21^{\text {st }}$ century's first civil rights movement” (Ross, 2015).

Although these women began the movement due to the acquittal of George Zimmerman, this one incident was not enough to turn the small movement into the national movement that it has become. The fuel the movement needed to gain prominent, national attention were the deaths of other unarmed, "black Americans [by police officers] —like Tamir Rice, Michael Brown, Eric Garner and Freddie Gray" (Collins \& Mak, 2015). These collective incidents made people begin to realize that there truly was a problem that needed to be addressed in the United States. According to the Black Lives Matter website (www.blacklivesmatter.com), the problem is "virulent anti-Black racism that permeates our society." Others characterize the problem as systemic racism built into the American criminal justice system and the ideals and beliefs that the country were founded upon. However people saw the problem, the Black Lives Matter movement and hashtag allowed those people to unite under a common cause to form with strength in numbers.

\section{The Shooting in Ferguson, Missouri}

The real upswing in national attention came from the major incident in Ferguson, MO in August of 2014. A black teenager named Michael Brown was fatally wounded by a white police officer named Darren Wilson. The incident occurred after Brown and another individual had been reported to have stolen cigarillos from a local convenient store. Witnesses and Wilson describe an altercation and a foot chase took place before the fatal shot (What Happened in Ferguson?, 2014). After the shooting, the jury did not indict Wilson. Wilson's defense was that 
Brown was attacking him, and he used the necessary force to protect himself. Once again, the composition of the jury was predominantly white with nine white jurors and three black jurors.

The following events are what put the Black Lives Matter movement and Ferguson in the national spotlight. There were protests all across the country in cities such as New York and Los Angeles in opposition of the decision made by the grand jury. The nation watched as the protests in Ferguson turned violent as people were so angry they began to riot. "St. Louis police, dressed in riot gear, stood in a straight line, shields up and face masks down in a standoff with protestors. The media assembled on the sidelines, cameras poised to capture the latest. There was tear gas, burning buildings, chants and signs" (Luibrand, 2015). Ferguson turned from a town no one had heard of to a town filled with news anchors from every major network. This tragedy gave the Black Lives Matter movement a platform and reason to speak out louder than it ever had before. "Protesters came armed with a message, a message that would echo through the Missouri night sky in the days and weeks after Michael Brown's death" (Luibrand, 2015). Messages and chants shouted "black lives matter" online and offline, and the media and the nation finally heard the message that the movement had been sending for over a year. The movement was calling for change. A change to the systemic racism of the country and the way that police dealt and interacted with minorities (Luibrand, 2015).

\section{Metaracism}

The fatal shooting of Michael Brown was incredibly tragic; however, there is another tragedy that has existed and continues to exist in this nation that is highly exhibited in the St. Louis area, where Ferguson is located. It is segregation. Although, the official and explicit racial caste system of the Jim Crow Laws and way of life were legally abolished in the 1960s (Pilgrim 2000), segregation still persists in this country. 
The phenomena that has allowed segregation and the oppression of black lives to continue is called metaracism. Wilson (2015) defines metaracism as,

A form of racism without hateful bigots. It replaces biological determinism with cultural determinism. It no longer dehumanizes all blacks. It accepts the black middle class, but promotes dehumanizing images and stories of welfare queens, teenage girls having babies to get welfare, and black teen thug culture. It involved the strategic use of race in the assault on progressive politics and the support of extreme inequality. It provides the images and narratives that support the neoconservative and neoliberal ideologies and that energize reactionary political movements.

Metaracism has paved the way for politicians to enact policies and regulations that negatively affect black lives more than others, whether intentional or not. The definition of reactionary pertaining to culture on dictionary.com is "an extremely conservative person or position that not only resists change but seeks to return to the 'good ole days' of an earlier social order". This type of behavior is accurately displayed in the Tea Party calling President Barack Obama a tyrant by implementing the economic stimulus package during the Great Recession to help the economy recover and enacting the Affordable Care Act, aka Obamacare, to help some of the millions of uninsured people obtain affordable health care (Wilson, 2015). This type of reactionary behavior travels back 50-60 years ago. Politicians began to realize that they could not call black people the "n word" or explicitly advocate for policies that were inherently racist. Instead, politicians began to exploit racial fears without mentioning race by using code words and focusing on the arrogant and excessive use of federal power, states' rights, crime and welfare (Wilson, 2015). It allowed for black men to continue to be thought of as the "strapping young buck" that was inherently violent, defies white authority and is here to rape all white women. 
Wilson (2015) writes:

[Metaracism] is related to the expansion of black poverty, the spatial concentration and isolation of the black poor, a split between the black poor and the black middle class, and the rise of mass incarceration, with more black men in jail and prison than ever before in US history (p. 26).

A prime example of the use of these code words is in 1963. George Wallace, a candidate for Alabama governor, had lost the race to a blatant racist candidate, while Wallace was known for treating all people fairly and even spoke of the welfare of the poor. Four years later, he campaigned on the promise to continue segregation. When a court order was enforced to integrate black students into the University of Alabama, he stood in front of the door in opposition. During his inauguration, he defended segregation and was nationally ridiculed. Several months later, he gave a speech that defended states' rights instead of segregation. "States' rights [were] a paper-thin abstraction from the days before the Civil War when it meant the right of Southern States to continue slavery" (Wilson, 2015).

Although segregation is not still maintained on the basis of states' rights, it is maintained through other means as blatantly displayed by the St. Louis school system. According to Hannah-Jones (2014),

"St. Louis yielded some of the starkest racial dividing lines in any American city, North or South," said Colin Gordon, a University of Iowa professor who traces this history in his book "Mapping Decline: St. Louis and the Fate of the American City." "I like to think of St. Louis not as an outlier, but one in which all the things we're talking about are just more visible." 


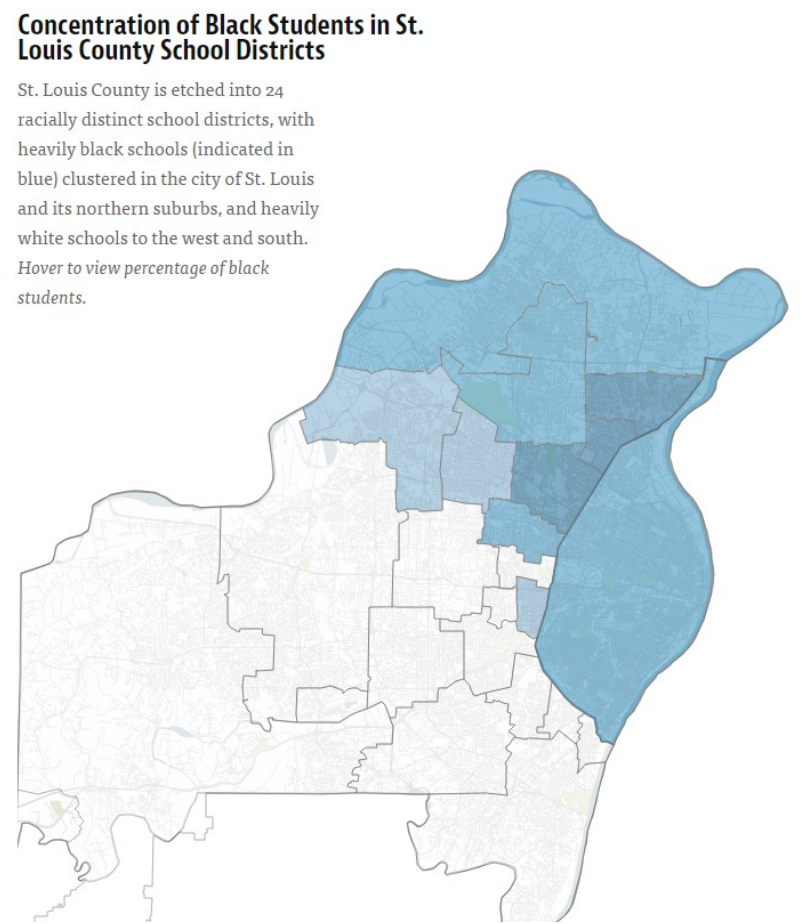

Starting after the end of slavery, numerous amounts of former slaves began moving to St. Louis. This was referred to as the "negro invasion". The white people of St. Louis began to create barriers to bar blacks from the white neighborhoods. "St. Louis became the first city in the country to require housing segregation by popular ballot" (Hannah-Jones, 2014). After that was struck down in court, other barriers came in the form of clauses that prevented the sale of homes in white neighborhoods to blacks. This also was struck down in court, and by 1970, St. Louis had lost $60 \%$ of its white population. The people that moved from the heart of the city created 90 little towns outside of St. Louis, and used similar barriers to bar black people from buying homes.

During this time of the "exodus of the whites" from St. Louis, the Brown v. Board of Education decision was made, which required schools to integrate. The officials of St. Louis found a way to "get around" the court's decision. They did not officially say black students could not attend schools because they were black. The officials drew school district lines around 
racially segregated neighborhoods. Students within these district lines had to attend the schools within their district. With the strategically crafted school district lines along racial divides, schools remained segregated. Successful attempts have been made to integrate the schools. However, they have only been short lived because they have always been undermined by those that seek to uphold the segregation of schools under the guise of the integration programs being too expensive or other reasons that have ultimately allowed the programs to be dismantled. In the 80 's, over 15,000 students were placed in the integration program and bussed to and from the predominantly white schools and to magnet schools inside of St. Louis. "The plan successfully broke the deeply entrenched connection between race, ZIP code and opportunity" (HannahJones, 2014). Although this plan was successful, Attorney General Jay Nixon and supporters eventually succeeded in destroying the program. The program is still in existence today, but only a third of the number of students that participated in the 80's participates now. This left thousands and thousands of black students in segregated, inferior schools.

Michael Brown was one of those thousands of students that was left to attend the numerous substandard schools that the segregation of St. Louis created. Normandy, the school Michael Brown attended that is $97.5 \%$ black students and ranks the lowest in the state on academic performance, is just 5 miles from a predominantly white school that has just $18.8 \%$ black students (Hannah-Jones, 2014). According to the Missouri Department of Elementary and Secondary Education, this graph below illustrates some differences between Clayton and Normandy. 


\section{The Difference Between Clayton and Normandy}

Five miles separate the Clayton and Normandy school districts, but much more sets them apart. Here are some characteristics of the two districts from the 2013-2014 school year.

$\begin{array}{lrr} & \begin{array}{c}\text { CLAYTON } \\ \text { Accredited }\end{array} & \begin{array}{r}\text { NORMANDY } \\ \text { Unaccredited }\end{array} \\ \text { 4-year graduation rate, white students } & 96.3 \% & \begin{array}{r}\text { Too few students to accurately } \\ \text { determine }\end{array} \\ \text { 4-year graduation rate, black students } & 93.8 \% & 61.4 \% \\ \text { Average teacher salary } & \$ 71,205 & \$ 59,560 \\ \text { Average spending per pupil } & \$ 17,851 & \$ 15,096 \\ \text { Percentage of high school core classes not } & 1.0 \% & 39.7 \% \\ \text { taught by "highly qualified" teachers } & & 16 \\ \text { Composite ACT score (national average: } 21) & 25.7 & \\ & & \end{array}$

This is just a small glimpse into the vast disparity of the segregation of the St. Louis school districts and the entire nation's segregated schools. Michael Brown's death was a tragedy, but the circumstances and opportunities he was given were just as much or more of a tragedy because millions of students of color are placed in segregated schools that do not adequately prepare them like their white counterparts.

This tragedy can also be referred to as systemic racism. This is described as forms of racism which are engrained into political and social institutions. It occurs when organizations, institutions or governments discriminate, either deliberately or indirectly, against certain groups of people to limit their rights (Institutional Racism, n.d.). This is exactly what is happening when black students are placed together in subpar schools that consistently underperform and not enough, if anything at all, is being done to help these schools and these students. Systemic racism and metaracism has contributed to the culture of colorblindness towards people of color. 
Colorblindness is the "racial ideology that posits the best way to end discrimination is by treating individuals as equally as possible, without regard to race, culture, or ethnicity” (Williams, 2011). Although this seems like a good solution, it is a form of racism in itself. It allows white people to not recognize that racism exists and that people of color have experience difficulties due to their race throughout their entire lives. "Colorblindness creates a society that denies their negative racial experiences, rejects their cultural heritage, and invalidates their unique perspectives" (Williams, 2011). This is one reason why Black Lives Matter had to happen.

\section{Leadership of Black Lives Matter}

Although Garza, Cullors and Tommetti are the founders of the movement, they are not the leaders of Black Lives Matter. In fact, the organization is decentralized and leaderless. The movement is following the model of other social movements that have chosen the leaderless route. The leaderless option is beneficial because it avoids the problems that allowing one person to be in charge, and it specifically goes against the governmental structure that is oppressive and the reason the movement began. "A common misconception is that the movement is leaderless. But...it's actually 'leader-full', and not being under the rule of one or two people allows many people to pursue change in the way they believe most beneficial and in a decentralized manner" (Luibrand, 2015).

However, not having a leader poses a major problem. Whenever Black Lives Matter protesters appear at events or rallies or speak out, no one knows whether or not it is an official Black Lives Matter member or just a person that decided to say something and tack on the movement's name to give them more credibility. It makes it hard to determine which direction the movement is headed. Some protestors have taken to the peaceful route, while others have decided to take a more violent route, such as the events that took place in Ferguson. Still others, though they may not be violent, they certainly are not peaceful. They aggressively interrupt 
presidential candidates' events and speeches to demand their voices be heard. "The demonstrations are peppered with hate speech, profanity, and guys with sagging pants that show their underwear" (Reynolds, 2015). This approach to civil rights is distinctly different than the Civil Rights Movement of the 1960's. These activists were "trained in the tradition of Martin Luther King Jr., [and] were nonviolent activists who won hearts by conveying respectability and changed laws by delivering a message of love and unity" (Reynolds, 2015). Civil rights activists from the Martin Luther King era have a hard time supporting the movement due to its abrasive and confrontational mentality.

The absence of a main leader also makes conveying messages difficult. For example, after two women interrupted Bernie Sanders' political rally in Seattle, a 16-year old high school student named Nikki Stephens, who was in charge of one of the Black Lives Matter in Seattle Facebook page, wrote an apology to Bernie Sanders and his supporters. She wrote this apology because people thought she was responsible for the incident that took place during the rally. Once Stephens did this, the media thought that the Black Lives Matter organization had apologized (Collins \& Mak, 2015). However, the women that were responsible contacted Stephens and demanded she change the name of her page arguing she did not have any right to the Black Lives Matter: Seattle Facebook page name. After that, those women created a Facebook page called "Black Lives Matter Seattle" and issued a statement with \#BowDownBernie in the title. Later on, another Facebook group demanded an apology from Sanders and his supporters. Finally, the official organization issued this statement: "The \#BlackLivesMatter organization did not create any petitions demanding apology from Seattle based organizers. We have not issued a public apology, neither have we made any public statements demanding an apology" (Collins \& Mak, 2015). 


\section{Black Lives Matter and Social Media}

There is no denying that social media has played an integral part in the prominence of Black Lives Matter. It all began with the Facebook post from Alicia Garza, as stated before, and took off from there. The hashtag of \#BlackLivesMatter was created in July 2013, but was not utilized very much. In July 2014, it was only being used 48 times per day, which only equals about 18,000 total tweets (Memby, 2016). It was being used in ways that were not being used in political nature. This was just one short month before Michael Brown was shot and killed in Ferguson. However, in August, after the Michael Brown shooting, the number of tweets totaled 52,000 (Memby, 2016). The big spike in tweets came with the November 25, 2014 decision to not indict Darren Wilson, the police officer that killed Brown. In the 20 hours following the decision, \#BlackLivesMatter was tweeted 10,000 times (Memby, 2016). "In the four hours of that day following the verdict, it was used 92,784 times" (Memby, 2016). The graph below shows where "researchers graphed when tweets about Black Lives Matter and police shooting victims rose and fell in usage on Twitter" (McLaughlin, 2016).

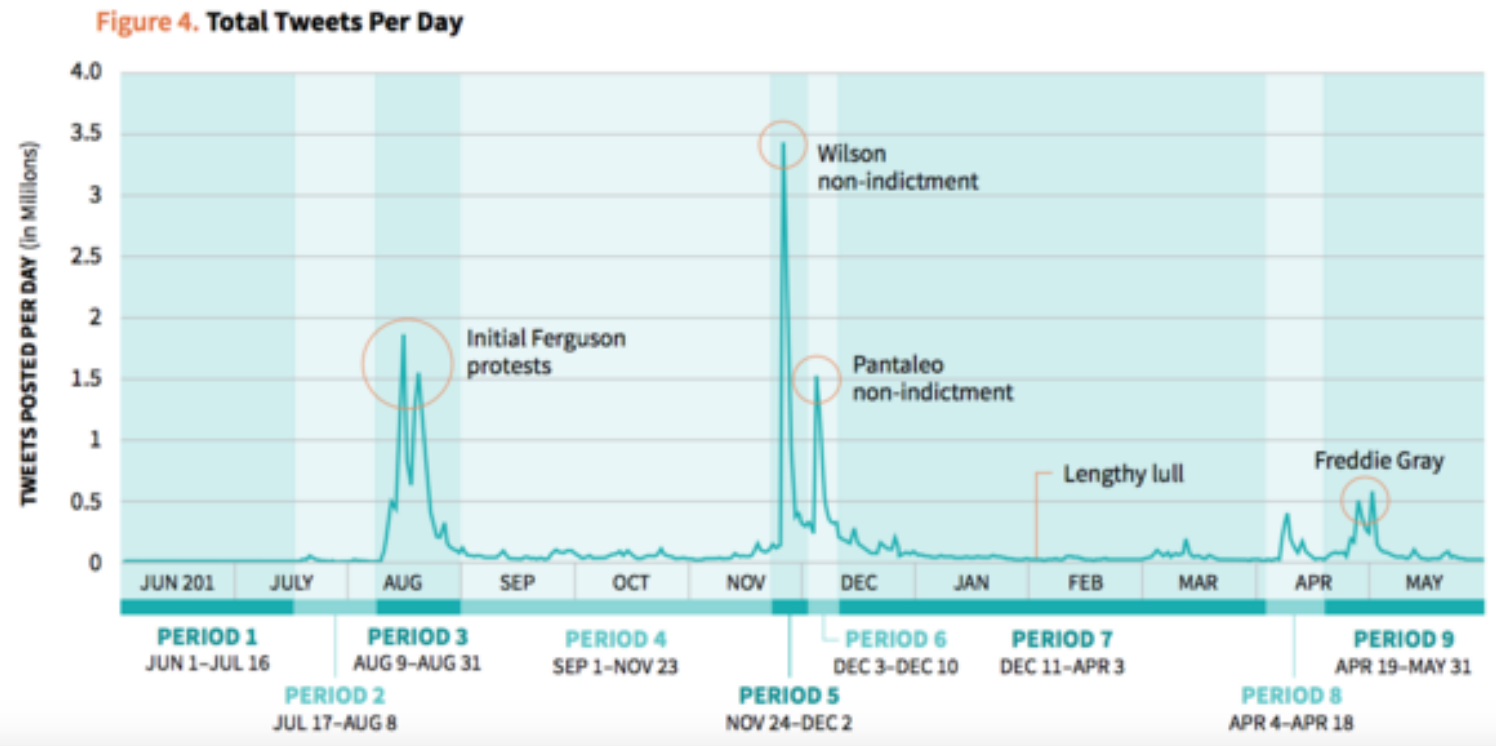

Although \#BlackLivesMatter could be considered the main hashtag because it bears the name of the organization that was formed, there have been many other hashtags that are related 
and relevant to the Black Lives Matter movement. Some of those are \#handsupdontshoot, \#icantbreathe, \#ericgarner, \#Ferguson, \#michaelbrown and many others. Many of these hashtags received more hits than \#BlackLivesMatter. During the study period of June 2014 to May 2015 by Charlton McIlwain, Deen Freelon and Meredith Clark, \#ericgarner was attached to 4.3 million tweets, \#michalebrown/mikebrown was included in 9.4 million tweets and \#Ferguson was attached to an overwhelming 21.6 million tweets (Memby, 2016). This speaks to the incredible attention that Michael Brown and Ferguson received. The graph below shows "the 10 most widely used keywords on twitter that were associated with Black Lives Matter" (McLaughlin, 2016).

Table 3: Twitter keywords and relevant metadata

\begin{tabular}{l|ll|r}
\hline KEYWoRD(S) & DATE KILLED & LOCATION & NUMBER OF TWEETS \\
\hline $\begin{array}{l}\text { \#ferguson } \\
\text { "michael brown"/"mike brown"/ }\end{array}$ & N/A & N/A & $21,626,901$ \\
\#michaelbrown/\#mikebrown & Aug 9, 2014 & Ferguson, MO & $9,360,239$ \\
\#blacklivesmatter & N/A & N/A & \\
"eric garner"/\#ericgarner & July 17, 2014 & Staten Island, NY & $4,312,599$ \\
"freddie gray"/\#freddiegray & Apr 19, 2015 & Baltimore, MD & $4,286,350$ \\
"walter scott"/\#walterscott & May 4, 2015 & North Charleston, SC & $2,559,316$ \\
"tamir rice"/\#tamirrice & Nov 22, 2014 & Cleveland, OH & $1,083,316$ \\
"black lives matter" & N/A & N/A & $1,001,971$ \\
"john crawford"/\#johncrawford & Aug 5, 2014 & Beavercreek, OH & 445,514 \\
"tony robinson"/\#tonyrobinson & Mar 6, 2015 & Madison, WI & 331,793 \\
\hline
\end{tabular}

Traditional media outlets have followed Black Lives Matter extremely closely reporting on prominent figures giving praises, criticisms and condemnations of the movement. Praise: "Barack Obama defended the Black Lives Matter movement from its critics on Thursday, saying the campaigners had raised genuine problems that should be tackled as part of criminal justice reform” (McCarthy, 2015). Criticism: Ben Carson (2015) says, 
The 'Black Lives Matter' movement is focused on the wrong targets, to the detriment of blacks who would like to see real change and to the benefit of its powerful white liberal funders using the attacks on Sanders for political purposes that mean nothing for the problems that face our community" (Carson, 2015).

Condemnation: "Gov. Chris Christie said Sunday the Black Lives Matter moment has created an environment that has called for the killing of police officers" (Acro, 2015). With social media becoming such an important part of society, almost everything that is aired on or posted to a website on the internet, undoubtedly ends up on social media outlets such as Facebook and Twitter. According to a 2015 study conducted by the Pew Research Center, $45 \%$ of U.S. adults obtain their news from Facebook, Twitter, or both outlets (Lichterman, 2015). In the case of the $45 \%$ of the U.S. adults (over 110 million people) that receive their information from these social media outlets, they have all had the opportunity to hear about Black Lives Matters praises, criticisms, and condemning solely through there. These people will have formed their opinions on whether they are supporters, opponents, or neutrals from what they have seen on social media. Everyday people are posting, tweeting, liking, "favoriting", commenting on, sharing, and retweeting positive, negative and neutral posts that are dealing with Black Lives Matter, racial injustice, police brutalities and other issues that are related to Black Lives Matter and their mission.

Besides the traditional forms of media being transferred onto social media, there has been a plethora of original information posted to social media websites from people reacting to what they are seeing on the news and from people that are actually involved in protests, riots and activists' events. Take the journey of DeRay Mckesson for example. He is a 29 -year-old, former school administrator, black man from Baltimore that has spent a lot of time travelling to join 
protests across the country. From actively participating in protests, Mckesson's follower base on Twitter has grown from less than 900 to more than 344,000 that he communicates with live from the protests that he attends. The catalyst that pushed Mckesson to join the protests across the country was the vast disparity between the "sensational accounts of rioting he saw on television and the reports he was reading on Twitter from people in Ferguson, who claimed that the cops had been firing tear gas and rubber bullets into crowds of peaceful protesters" (Kang, 2015). Since the shooting of Michael Brown on August 9, 2014 according to Kang (2015), Mckesson and a core group of other activists have built the most formidable American protest movement of the 21 st century to date. Their innovation has been to marry the strengths of social media - the swift, morally blunt consensus that can be created by hashtags; the personal connection that a charismatic online persona can make with followers; the broad networks that allow for the easy distribution of documentary photos and videos - with an effort to quickly mobilize protests in each new city where a police shooting occurs.

Although police shootings are not necessarily on the rise, people like Mckesson and the entire Black Lives Matter movement have brought a national spotlight to the issue and the broader issue of police mistreatment towards blacks and the racism that is built into the criminal justice system and American society as a whole.

\section{Discussion}

Social media was Black Lives Matter's bridge to create a community which led them to real, meaningful action and change. From June 2014, before the tragedy in Ferguson occurred, to May 2015, there were 41 million tweets related to Black Lives Matter on Twitter (Memby, 2016). A vast number of these tweets related to the Black Lives Matter movement were related 
to people actually being out on the ground protesting for what they believed in, whether that was protesting the numerous amounts of wrongful deaths that were occurring, protesting the system that refused to punish the officers and people that were responsible for the deaths, or being used to bring attention to different injustices that occurred in their everyday lives.

All of the social media activism, traditional media attention and traditional forms of activism such as protesting in person have led to actual changes at multiple levels of government. Many police departments are requiring their officers to wear body cameras to hold them more accountable and retraining the officers to attempt to correct the racial profiling and bias that has existed for decades. The activism has reached to the highest levels of the government to the 2016 Presidential Candidates. Criminal justice reform, racial injustice, income and economic inequality and other subjects related to the Black Lives Matter movement have all been hot topics during the presidential debates, especially in the Democratic debates. Bernie Sanders has an entire section of his website dedicated to racial justice on his official campaign website for President.

The Black Lives Matter movement is saying that business cannot continue as usual. The movement will not let things continue how they have been for the past several decades. The activists have proved this to be true. For example, black students at the University of Missouri took matters into their own hands after there was a petition started calling for the University President, Tim Wolfe, to resign because they felt "he had not done enough to address racism on campus" (Kingkade, 2016). According to Kingkade (2016) from the Huffington Post, On Oct. 10, a group of black students interrupted the Mizzou homecoming parade. Wearing T-shirts that read "1839 Was Built On My B(1)ack,” referring to Mizzou’s founding and slave labor, the students stopped right in front of the convertible that [Tim] 
Wolfe was traveling in as he waved to parade watchers. The students took out a megaphone and one by one began speaking about incidents of systemic and anecdotal racism from the founding year 1839 through 2015.

These students were determined to not let the parade continue without their voices being heard. There were plenty of people trying to get them to move, but they stood their ground. The football team joined in the protesting by supporting a graduate student named Jonathan Butler going on a hunger strike until Wolfe resigned or Butler himself died. "University of Missouri's football team said it would boycott all football-related activities until university system president Tim Wolfe resigned or was fired. Two days later, Wolfe stepped down" (Nadkarni \& Nieves, 2015). This is just one example of how activists are not letting business continue as usual. There is a plethora of others.

The idea that being colorblind to race has contributed to the racial injustice that has pervaded America and led to activism like that at Mizzou. The argument from white people is that "I don't see color", so you should not either. This is a flawed mentality because it denies people of color to be able to call attention to the trials and tribulations that they face and ignores that racism exists. This idea has also helped to make talking about race somewhat of a taboo in our society. People get uncomfortable when it comes to talking about race, especially white people. White people claim that people of color always play the "race" card in situations that white people feel race should not be brought up. However, if people of color did not have to think about how their race plays a factor in their lives each and every day, like white people have the privilege of doing, then they would not. The fact that discussing race has been seen as a taboo is part of the problem. This is one of the many reasons Black Lives Matter needed to come to fruition. These problems will never go away and racial tensions will not be reduced until 
everyone acknowledges that racism does still exist in America today, becomes involved in the conversation on how to address the racial injustices that permeate our society, and act on the steps towards a solution.

Implications for Activists:

\section{$\underline{\text { Implications }}$}

- If used in the correct way, social media is a powerful tool. It can be used to further a cause, gain awareness and gain followers and activists. From the examples of Occupy Wall Street, Arab Spring, and Black Lives Matter, there was and continues to be meaningful change that social media played a huge role in making that change happen.

- Although social media is a powerful tool, it cannot be used alone to enact positive, lasting change. Social media must be paired with the traditional forms of activism, such as protesting. Lawmakers and the opposition must be able to see that the activists truly mean business by going out and giving of their time and disrupting normal activities before meaningful change can happen, just like the Black Lives Matter movement did.

- For those budding activists that want to support a cause by giving of their time but are afraid to waste their time, activism truly does work. It may take a while, but it can work. From the Black Lives Matter case analysis, the movement has observed change in police procedures across the country including retraining officers and requiring officers to wear body cameras to hold them accountable for their actions. Therefore, get out and support the causes that you truly believe in.

- For those that are currently activists for a cause, keep protesting and fighting for what you believe in because there is great power in passionate activism. As stated above, the tireless work of the Black Lives Matter activists has gained the attention and action from 
the Democratic Presidential Candidates by addressing the concerns of the movement through changes in the respective candidates' campaign platforms.

Implication for Marketers

- Social media is a powerful tool. Just as it is powerful for activists to further their cause and other reasons, it works just as well for marketing companies. In this day and age, if a company is not on social media, it is hard for it to succeed. People expect a company to have a social media presence. The Pew Research Center found that $45 \%$ of U.S. adults obtain their news from either Facebook, Twitter or both. This news can be about a company, politics, weather, events, or others. This is an indicator of the power of social media. Marketers can gain massive amounts of new customers through correctly and actively being engaged on social media.

\section{Conclusion}

In this thesis, the role of social media and social movements has been examined with specific regard to the Black Lives Matter movement with the theories of collective identity, slacktivism and the role racial injustice in the $21^{\text {st }}$ century. Through collective identity, it has been shown that a shared sense of "we-ness", emotional investment and a dissociative group are extremely important to creating a collective and laying the foundation for a social movement to form. Slacktivism displayed that the token forms of support are not the way to create lasting change. Meaningful forms of activism like protesting must be used to enact meaningful and lasting change. However, coupling token forms of support and meaningful forms of support are a good strategy to achieve the meaningful change desired. This thesis has illustrated how racial injustice has been engrained into American society for scores of years, whether that be in policies promoted and endorsed by political candidates or through school segregation. Racial 
injustice is real and has to be addressed in constructive ways. The Black Lives Matter movement has been examined from its beginning, the immediate events that led to its creation and some of the impact that it has had in America. Black Lives Matter is not just a hashtag, not just a movement. It is the culmination of a history that has consistently illustrated that black lives do not matter. 


\section{Reference List}

Acro, M. (2015, October 25). WATCH: Christie says Black Lives Matter encourages killing cops. Retrieved March 02, 2016, from http://www.nj.com/politics/index.ssf/2015/10/christie_face_the_nation.html

Botelho, G., \& Yan, H. (2013, July 14). George Zimmerman found not guilty of murder in Trayvon Martin's death - CNN.com Retrieved November 9, 2015.

Bregstone, P., \& Chavez, M. (2012, May 9). Silver Chips Online : Pro/Con: Can Internet activism replace traditional forms of activism? Retrieved February 08, 2016, from http://silverchips.mbhs.edu/story/11596

Carson, B. (2015, September 03). Ben Carson: \#BlackLivesMatter misfire. Retrieved November 02, 2015, from http://www.usatoday.com/story/opinion/2015/08/24/blacklivesmattersanders-clinton-anger-column/32055507/

Collins, B., \& Mak, T. (2015, August 15). Who Really Runs \#BlackLivesMatter? Retrieved September 14, 2015.

Day, E. (2015, July 19). \#BlackLivesMatter: The birth of a new civil rights movement. Retrieved September 16, 2015.

Egypt. (n.d.). Retrieved November 1, 2015, from http://topics.nytimes.com/top/news/international/countriesandterritories/egypt/index.html

Essig, K. (2014, January 2). Activism Or Slacktivism? How Social Media Hurts And Helps Student Activism. Retrieved February 08, 2016, from http://news.stlpublicradio.org/post/activism-or-slacktivism-how-social-media-hurts-andhelps-student-activism

Fominaya, C. F. (2010) Collective identity in social movements: central concepts and debates. Sociology compass, 4, 393-404. 
Forman, C. (2015, December 31). What Black Lives Matter Achieved In 2015. Retrieved February 24, 2016, from http://www.theatlantic.com/politics/archive/2015/12/black-livesmatter/421839/

Hannah-Jones, N. (2014, December 19). School Segregation, the Continuing Tragedy of Ferguson. Retrieved March 01, 2016, from https://www.propublica.org/article/fergusonschool-segregation

Hwang, H, \& Kim, K. (2015) Social media as a tool for social movements: the effect of social media use and social capital on intention to participate in social movements. International Journal of Consumer Studies. 39, 478-488.

Institutional Racism. (n.d.). Retrieved April 18, 2016, from http://www.racismnoway.com.au/teaching-resources/factsheets/32.html

ISIS uses social media to recruit Western allies. (2014, August 29). Retrieved November 1, 2015, from http://www.cbsnews.com/news/isis-uses-social-media-to-recruit-westernallies/

Kamel, S. (2014) Egypt's ongoing uprising and the role of social media: Is there development?, 20, 78-91.

Kang, J. C. (2015, May 09). 'Our Demand Is Simple: Stop Killing Us’. Retrieved March 02, 2016, from http:/www.nytimes.com/2015/05/10/magazine/our-demand-is-simple-stopkilling-us.html?_r=1

Kavada, A. (2015) Creating the collective: Social media, the Occupy Movement and its constitutions as a collective actor. Information, Communication \& Society, 18, 872-886.

Kingkade, T. (2015, November 10). The Incident You Have To See To Understand Why 
Students Wanted Mizzou's President To Go. Retrieved April 19, 2016, from http://www.huffingtonpost.com/entry/tim-wolfe-homecomingparade_us_56402cc8e4b0307f2cadea10

Kristofferson, K., White, K., \& Peloza, J. (2014). The Nature of Slacktivism: How the Social Observability of an Initial Act of Token Support Affects Subsequent Prosocial Action. Journal of Consumer Research. Vol. 40 Issue 6, p1149-1166. DOI: 10.1086/674137.

Lichterman, J. (2015, July 14). New Pew data: More Americans are getting news on Facebook and Twitter. Retrieved March 02, 2016, from http://www.niemanlab.org/2015/07/newpew-data-more-americans-are-getting-news-on-facebook-and-twitter/

Luibrand, S. (2015, August 7). Black Lives Matter: How the events in Ferguson sparked a movement in America. Retrieved September 14, 2015.

Masi, A. (2015, February 28). ISIS Foreign Fighter Recruitment, Social Media Undeterred By New Security Crackdowns. Retrieved November 1, 2015.

McCarthy, C. (2015, October 22). Obama praises Black Lives Matter movement for raising policing issues. Retrieved March 02, 2016, from http://www.theguardian.com/usnews/2015/oct/22/obama-black-lives-matter-movement-policing

McLaughlin, M. (2016, February 2). The Dynamic history of \#BlackLivesMatter Explained. Retrieved April 18, 2016, from http://www.huffingtonpost.com/entry/history-black-livesmatter_us 56d0a3b0e4b0871f60eb4af5

Memby, G. (2016, March 2). Combing Through 41 Million Tweets To Show How \#BlackLivesMatter Exploded. Retrieved April 18, 2016, from http://www.npr.org/sections/codeswitch/2016/03/02/468704888/combing-through-41million-tweets-to-show-how-blacklivesmatter-exploded 
Nadkarni, R., \& Nieves, A. (2015, November 9). Missouri football's strike, explained. Retrieved April 19, 2016, from http://www.si.com/college-football/2015/11/09/missouri-footballprotest-racism-tim-wolfe

Ngak, C. (2011, October 13). Occupy Wall Street uses social media to spread nationwide. Retrieved November 1, 2015.

Ortiz, E. (2015, December 27). These Are the Hashtags That Defined 2015. Retrieved February 23, 2016, from http://www.nbcnews.com/storyline/2015-year-in-review/twitter-s-topnews-hashtags-2015-include-prayforparis-lovewins-blacklivesmatter-n481081

Pilgrim, D. (2000, September). What was Jim Crow. Retrieved February 29, 2016, from http://www.ferris.edu/jimcrow/what.htm

Reynolds, B. (2015, August 24). I was a civil rights activist in the 1960s. But it's hard for me to get behind Black Lives Matter. Retrieved September 11, 2015.

Ross, J. (2015, August 19). How black Lives Matter moved from a hashtag to a real political force. Retrieved September 13, 2015.

Seay, L. (2014, March 12). Does slacktivism work? Retrieved February 08, 2016, from https://www.washingtonpost.com/news/monkey-cage/wp/2014/03/12/does-slacktivismwork/

Shin, L. (2015, March 26). The Racial Wealth Gap: Why A Typical White Household Has 16 Times More Wealth Than A Black One. Retrieved February 23, 2016, from http://www.forbes.com/sites/laurashin/2015/03/26/the-racial-wealth-gap-why-a-typicalwhite-household-has-16-times-the-wealth-of-a-black-one/\#5ca368526c5b

Social Media Addiction: Statistics \& Trends [INFOGRAPHIC]. (2014, December 30). Retrieved November 2, 2015 
Thompson, N., Greene, R., \& Mankarious, S. (2015, February 15). ISIS: Everything you need to know about the group - CNN.com. Retrieved November 1, 2015.

Top Twitter Topics of 2015. (n.d.). Retrieved February 23, 2016, from http://www.cbsnews.com/pictures/top-tweets-of-2015/4/

Trere, E. (2015) Reclaiming, proclaiming, and maintaining collective identity in the \#YoSoy132 in Mexico: an examination of digital frontstage and backstage activism through social media and instant messaging platforms. Information, Communication \& Society, 8, 901915.

What Happened in Ferguson? (2014, August 12). Retrieved November 9, 2015.

What is 'Islamic State'? - BBC News. (2015, October 8). Retrieved November 1, 2015

Williams, M. T. (2011, December 27). Colorblind Ideology Is a Form of Racism. Retrieved April 18, 2016, from https://www.psychologytoday.com/blog/culturallyspeaking/201112/colorblind-ideology-is-form-racism

Wilson, C. A. (2015). Metaracism: Explaining the persistence of racial inequality. Boulder, CO: Lynne Reinner. 